\title{
The Reception of Ernest Hemingway in Iran after the Islamic Revolution: A study of The Old Man and the Sea and To Have and Have Not
}

\author{
Alireza Anushiravani \\ Department of Foreign Languages \& Linguistics, Shiraz University, Iran \\ Atefeh Ghasemnejad (Corresponding author) \\ Department of Foreign Languages \& Linguistics, Shiraz University, Iran
}

Received: 18-02-2017

doi:10.7575/aiac.ijclts.v.5n.2p.1
Accepted: 27-03-2017

Published: 30-04-2017

\begin{abstract}
This article investigates how the literary reception of Ernest Hemingway in Iran in the first two decades after the Islamic Revolution is formed by cultural and ideological implications. The theoretical framework of this study is based on S.S. Prawer and Roger Asselineau's notion of reception theory as a branch of study in comparative literature. The methodology entails a chronological study of translations, and cinematic adaptations of the author's oeuvres. This study devotes itself to the study of the two most reprinted and translated works which depict a huge difference in the number of translations and reprints compared to Hemingway's other works. As Such, the following outcomes are deliberated: besides the international fame of Hemingway, his continuing success in Iran can be related to the ideology of the translator, and the director, who deploy Hemingway's novels as a prism to reflect Iranians' stoic perseverance and mythical desire for freedom and fight against despotism as manifested in the legend of Jamshid. Hemingway's code hero, undergoing stoic perseverance in hardship and war embody Iranians' passage through a turbulent historical event after Revolution. Struggling with unemployment, war, and frustrated hopes, Iranians find Hemingway's novels as a way to cope with arising problems during and after war. This article also explicates why reception of this particular work in Iran differs from its universal trend.
\end{abstract}

Keywords: Iranian Dream, Stoicism, Legendary and Historical Fight against Despotism, Freedom, Ideology of the Translator.

\section{Introduction}

Persian literary scholars such as Mirsadeghi, Mirabedini, Baraheni, and Sepanloo unheeded reception studies as a serious literary concern that can illuminate the contextual features of a given era, granting enduring reception of certain authors or oeuvres while hindering others. This study follows S.S. Prawer's example of George Asselineau's practical model in his article titled as "French Reactions to Hemingway's Works between the Two World Wars." It should be noted that S.S. Prawer's reception study is a field of study within comparative literature and is not subject to either reader response theory or the Constance School. Investigating a chronological study of translations of Hemingway's novels, reviews, preface of the translator, and the literary taste of a nation, Asselineau discusses the fluctuations in the literary reception of Hemingway's fiction in France (Prawer 32-33). Prawer marks that Asselineau's study deals initially with "the chronology of translation of Hemingway's work ... together with the articles and reviews they provoked as they appeared" (32). Asselineau examines the status and fame of the publishing firm and the translator. He also considers the translator's preface or reviewers' contribution to the fame of the author. The chronological study of translations indicates that there was an early period of "French interest," in Hemingway's works "followed by a lull, followed by a renewed interest in 1931-1932" (Prawer 32). This "renewed interest" (Prawer 32) is kindled by a robust translator, M. E. Coindreau, who published A Farewell to Arms by Gallimard, one of the most prominent publishing firms in France. Asselineau believes that Hemingway's literary fortune owes much to the status of the publisher and the publication who provided Hemingway with more serious and academic reviewers and readers. He also notes that M. E. Coindreau later in an article titled as "l'Amérique et le roman alchoolique" renounced Hemingway's artistic talent and the "tough guy" image that Hemingway and his characters promoted (Asselineau 47). Asselineau calls it "a venomous attack full of vitriolic personal allusions" (Asselineau 47) which had a "sobering effect" on the critics and reduced interest in Hemingway (Asselineau 49). Another reason for reception of Hemingway in France, as Asselineau puts it, lies in French literary taste rooted in the historical context of France where Hemingway's fiction was embraced enthusiastically. Asselineau argues that World War I gave rise to the popularity of Hemingway in France. People who had experienced the atrocities of war wished "to read, to be diverted, to forget the horrors through which they had been, or to recollect in tranquility the emotions they had experienced" (Asselineau 51). In addition, they wished to make sense of "what happened (and why it happened) during the nightmarish years of the Great War" (Asselineau 51). This 
encouraged "fiction writing" and "novel of action or adventure" (Asselineau 51). The next, was "a desire for a change if not of subject matter at least of tone" (Asselineau 51). The younger generation blamed the older one for the war and its aftermath. Novels of Hemingway, which give voice to the youth, alleviate their horrors of war. Asselineau also refers to "economic prosperity," the consequent "boom" in publishing industry, and "a desire for escape and exoticism" as other agents that influenced Hemingway's reception in France. The tendency of French people to either travel as tourists or to "read books of travel or of adventures in distant lands" (Asselineau 51) promoted reading of Hemingway's fiction. "French intellectual curiosity", at this conjuncture, wanted to find out was happening in other countries (Asselineau 51). Also, the prefaces written by the writers who indulged in "a new faith in man" and resisted to give in to despair and "nihilism" augmented the reading of Hemingway (Asselineau 52). This elaborate contextual background against which translations of Hemingway occurred justifies the fluctuations in Hemingway's literary fortune in France.

As seen above, the chronological study of Hemingway's translation in France is a means of analyzing the French interest in Hemingway. This article, in line with Prawer and Asselineau's trajectory, opens the discussion with a chronological study of the Iranian interest in translation of Hemingway's The Old Man and the Sea, and To Have and Have Not, which were the first two works that were received warmly on the part of Iranian audience. The chronological review in the following section elucidates that while the former oeuvre enjoys a warm worldwide reception, the latter failed to continue its primary charismatic impact on Hemingway readers. Iranian interest, unpredictably, demonstrates an increasing interest in To Have and Have Not, the reason for which is later discussed in this paper. Clearly, the study of the literary fortune of an author, inexorably, entails a cultural and social study of that country.

\section{A Chronological Study of Translations and Adaptations of Hemingway's The Old Man and the Sea and To Have and Have Not in Iran}

A chronological study of the translations and adaptations of a certain writer or work, as the first step to examine the literary fortune of a particular writer or work, indicates a contextual study of the given work. It features the translators who promoted or hindered the interest in a certain work or writer. The attitude of the translator, usually prefaced to the translated text or published as a review, is an important factor in promoting the translation. Also, the fame of the translator and his virtuosity enhances the literary fortune of a work. The fame of the publishing firm is another agent in promoting the readership and literary fortune of a certain work. The chronological study of the reception of a certain work or author indicates the ups and downs or the possible lapses in the reception process, and provides the literary scholar with certain dates or periods when the literary fortune is either hindered or reinforced. Moreover, the background against which a certain work is received designates distinct contextual features that contribute to its reception.

Translation of Hemingway's The Old Man and the Sea took an upward trend after the Islamic Revolution of Iran in 1979. A brief review of the previous translations before the Revolution ratifies this surge: The first translation of the novel took place in 1952 by Reza Marashi. Yahyavi's translation also appeared in the same year. These translations were followed by Ahmad Shahriar's translation in 1969 and Nazi Azima's translation in 1975 by Amirkabir publishing firm, then the most important publishing firm in Iran. There is one more translation before the Revolution by Daryush Shahi via Sepideh Publications [n.d.]. The earliest translation after the Revolution belonged to Daryabandari in 1984 by Kharazmi Publications. There are reprints of this translation by the same publisher in 1993, 1994, 1998, 2006, 2010, and 2014. Najaf Daryabandari's curt, familiar language, and employment of nautical terms from South Iran are the chief elements that correspond to the translation's prominence and durability. For as inarticulate as these words might seem for Iranian audience who is not familiar with the Southern dialect, still, he identifies Santiago with an Iranian fisherman living desperately in an impoverished community wrestling with fate disregarding consequences: for as Santiago asserts "'man is not made for defeat'... 'A man can be destroyed but not defeated" (Hemingway 103). The significance of this stoic attitude is later discussed in terms of Iran's post-Revolution period.

Nazi Azima is another conspicuous translator whose translation by Amirkabir Publication and later Ofogh Publication is still eye-catching. Though, it was Daryabandari's translation with simple and curt language and familiar tone that exceeds all other translations in popularity, fame, and academic acclaim, Azima's translation exceeds in its reprints. After the Revolution, her translation was reprinted by two publishing firms. Ofogh publishing firm reprinted The Old Man and the Sea in March and December 2010, 2011, 2013, and July and December 2016. Amirkabir publications reprinted the novel after the Revolution in 2009, 2010, 2011, May and July 2012, and 2015. Obviously, the status of Amirkabir publishing firm, as the most significant publisher in Iran before the Islamic Revolution contributed to the fame of the translator. In addition to the publisher's fame, the attachment of a critique by Linda Wagner to the novel's translation and her addition of a robust introduction to the translation of the novel in reprints after the revolution are two cogent agents that contribute to the audience's reception of the translated text. Although Azima's criticism and text are academically correct, unlike Daryabandari, she avoids any regional association of the text with the Iranian dream or experience.

Whereas Azima's reprint of the novel after the Revolution was renewed two decades after Iran-Iraq war, Daryabandari's translation of The Old Man and the Sea was published in the course of Iran-Iraq eight-year war that lasted from 1980 till 1988. The boom in the publication of Hemingway novels and reviews in journals in the next decade following war suggests Iranians' added interest in Hemingway's display of stoic fortitude for a war-stricken community.

The next work that has gained unprecedented reception on the part of Hemingway's readers in Iran is Hemingway's To Have and Have Not. Initially, published in 1937, this novel is not esteemed as a great piece of work among 
Hemingway's oeuvres. The early reviews of the book were not as disappointing as its later criticism but as Mazzeno notes, "academic critics have generally regarded it as one of Hemingway's weakest books" (31). To Have and Have Not in Iran was translated before the Revolution by Parviz Daryoosh in 1961 also reprinted in 1977. The translation of this novel by Fereydoon Rezvanieh occurred in 1984 with its reprints in 1990 and 1991. Daryoosh's translation was also reprinted in 1989. In 1987, a free cinematic adaptation of the novel by Naser Taghvaei titled as Nakhoda [Captain] Khorshid during Iran-Iraq war was welcomed by the audience, turning this movie into a classic Iranian film overnight. This free adaptation also paves the way for a vast array of cultural, political, and societal implications meeting the demands of Bhabha for heterogeneity and innovations. Homi Bhabha in his assessment of the notion of hybridity, advocates the hybridity that inexorably "respects essential difference [since it] enables innovation, whereas the cultural synthesis or homogenization of multiculturalism proves stifling" (qtd. in Sanders 17). The hybrid nature of the cinematic adaptation is significant in its contribution to ancient and collective Iranian dream marked in symbolic associations discussed later in this article.

To Have and Have Not depicts Harry Morgan's efforts to grapple with the unremitting pressure of a Capitalist system that does not care for the survival of the Have Nots of the society, of which Harry serves an example. Harry Morgan smuggles liquor, political, and illegal immigrants, some of which embody felonious Have Nots. Naser Taghvaei, as the film script writer and the director of the movie adaptation alters the setting from Cuba to South Iran, to some abandoned city on the Persian Gulf. Along with some domestic prizes in the International Fajr Film Festival in 1987, this movie won Bronze Leopard and was nominated for Golden Leopard at Locarno International Film Festival in 1988 (Nakhoda Khorshid). The movie demonstrates Captain Khorshid as a pious Muslim who avoids smuggling liquor and opium simply because his religion and moral responsibility forbids him. This typical Persian man manifests features of a righteous man who, unlike Harry Morgan, evokes the sympathy of the reader early in the movie. Compared to Morgan, Khorshid does not murder anybody unless for the criminals who take his life in return.

After some sporadic and insignificant translations in the next decade, there is a rapid surge in the number of the translations in the first decade of the $21^{\text {st }}$ century. In addition to the reprints of Daryoosh's translation of To Have and Have Not in 2001, 2002, 2007, 2009, 2011, 2013, 2014 and 2015 in two publishing firms, Ofogh and Amirkabir, and reprint of Rezvanieh's translation in 2008; new attempt to translate the novel are observed in Khojasteh Keyahan's translation in 2009 by Ofogh publications with reprints in 2013 and 2014; and also M. Ghobraei's translation in 2009 with a reprints in 2013 and 2015. Ehsan Lamē' translated the same work in 2014 by Bootimar Publications and Kachooeian's translation in Goharshid publishing firm occurred in 2013 with a reprint in 2015, Ahmad Kasaei's translation in 2015 by Hermes is another noticeable fine translation. Among these translations, Amirkabir's fame has prolonged the fame of Daryoosh's translation.

In a war-stricken country like Iran, Hemingway's war novels such as A Farewell to Arms and For Whom the Bells Toll are expected to indicate an enthusiastic reception, however; the chronology of translations demonstrates a huge difference in the number of translations and reprints of the first two works discussed above, i.e. The Old Man and the Sea and To Have and Have Not, and Hemingway's other major works such as A Farewell to Arms and For Whom the Bells Toll. It is more interesting to note that although To Have and Have Not is not esteemed among Hemingway's major works, it ranks as the second most published work among Hemingway's works after the Revolution. A Farewell to Arms and For Whom the Bells Toll rank, with a drastic decline in number of translations and reprints are the next two most published works. The first reason lies in success of the film adaptation that provoked more translations. Also, this drastic difference can be justified by Iranian taste. Iranians at this historical juncture, during the first two decades after the Revolution, grappled with war and its aftermath. On the one hand, the revolution fever which was sparkled in the previous regime had already subsided. On the other hand, Iranians who had been immensely exposed to war movies and programs from the state-owned broadcasting channels turned to subjects that focused more on stoic perseverance than war. The following section is dedicated to explicate the surge in Hemingway readership and adaptation in Iran in terms of cultural, historical, and mythical associations.

\section{Hemingway's oeuvre as a prism reflecting Iranian dream after the Islamic Revolution}

Soon after the Revolution, Iran underwent what was termed as Imposed or Sacred War with Iraq. The war was initiated with Iraq's invasion upon the Iranian borders and lasted eight years from 1980 to 1988. Political crisis had its primary impact upon economic conditions. As Sadr notes the "decline" in "oil prices" (166) was accompanied by human casualties of war and economical paralysis including " 140,000 dead, 500,000 injured, and billions of dollars" (166). The economic crisis led to a drastic decline in unemployment, which, in turn, resulted in hectic efforts on the part of the jobless mob (Sadr 167) who:

...resort[ed] to individual survival strategies. The black market largely free from the bureautic control of the state, offered the only space in which individuals could exercise their own initiatives to better their lot and, in addition to relying on family, friends, and patrons, most found opportunities in casual work. (Sadr 167)

The atrocious situation had its immediate impact on the most vulnerable division of the society so that "the most desperate would do anything to ensure survival including begging, theft, drug-dealing and prostitution" (Sadr 168). This condition is also reiterated in Nasser Taghvaei's Captain Khorshid, the cinematic adaptation of Hemingway's To Have and Have not. Although the movie depicts the Pre-Revolutionary period in Iran and the hectic atmosphere caused by the spirit of revolution, the features of the era portrayed mostly resembles those of the post-Revolutionary period. For instance, Captain Khorshid who has already lost an arm mistakenly by the police, portrays a jobless man who is so desperate for feeding his family that he resorts to investing all his money in smuggling cigarettes. In addition, the 
Captain tells Mr. Farhan, a human trafficker, that he would not cooperate with Mr. Farhan in trafficking men to some deserted island instead of the Arabian countries across the Persian Gulf because "those guys you want me to ferry across the sea are a bunch of helpless and unemployed [my emphasis] people who are desperate to get money to feed themselves" (Nakhoda Khorshid. Dir. Naser Taghvaei). Unemployment, and the severe condition that people have to undergo as a consequence of war and the realistic representation of Hemingway's oeuvres find contextual resemblances with Iranian society during the first decade of war with Iraq.

In fact, cinema and literature can function as an essential asset in distributing the ideological apparatus of the State. The pivotal element of these fictive representations during the post-Revolutionary period contains a portrayal of a protagonist who comes from a despondent background leading a desperate life. This protagonist is inadvertently impelled to undergo a conflict with an antagonist who enjoying a position of power. The hero, as the plot unravels itself, is metamorphosed into a sacrificial patriot who maintains a symbolic presence. This recurrent leitmotif is especially witnessed in the first decade after the Revolution. This sacrificial goat whose blood waters and thus guarantees the succeeding peace for the residents of Iran is reminiscent of war documentaries and nonfiction movies that proliferated Iranian cinema during the first decade after Revolution. Captain Khorshid's blood, depicted as a devout Muslim in the movie, is in line with the religious associations of Iranian war with Iraq:

Iranian Shiites trace their primordial moment of identity back to the murder of Imam Hosain in Karbala, Iraq, at the hands of Sunni Arab caliphs in the seventh century. The war between Shiite-dominated Iran and Sunni-run Iraq paralleled this story in ways that the Iranian government—as well as filmmakers—used [...] fully (Nafisi 6).

As such, Captain Khorshid fortifies the significance of the Iranian Muslim's forbearance in the face of loss of the lives of thousands of people who died at the fronts at war. Identification of a dead soldier with a martyr - the highest religious rank obtained as a result of Jihad guaranteeing the afterlife in Paradise in Islamic Religion- and the proliferation of the war documentaries that promoted such ideology influence the religious significance of Khorshid.

In the same manner, Captain Khorshid touches upon Persian legendary overtones with symbolic significance. As Hoveyda implies the Revolution can be esteemed as a reincarnation of the old mythical fight between light and darkness as a result of Ahuramazda's or God's order since Shah representing Jamshid, the good and benevolent king committed the sin of "hubris" (39). As the legend goes:

There was a time when Ahura Mazda (God in the Zoroastrian religion), upset by humans' greedy and sinful behavior, withdrew light from earth and in the ensuing darkness our planet became the realm of Ahriman (the devil in Zoroastrianism), who supported tyrants. Then, one day, Jamshid ascended to the throne and started a rule of justice and progress. Ahura Mazda, pleased by his behavior and deeds, returned the light, thus forcing Ahriman, the Prince of Darkness, to flee the earth. Jamshid could therefore reconstruct the country... Overwhelmed by hubris and conceit, he forgot his indebtness to Ahura Mazda. He assembled the people and told them: "I have given you all this wealth and comfort. You should therefore worship me as your king and the master of the world." Disappointed by these words, Ahura Mazda once again withdrew light and as a result all the earthly splendor faded away and the tongues of the people grew bold against

Jamshid. (Hoveyda 38-39)

Hoveyda firmly believes in the pattern of repeated occurrence of mythical interpretation in Iranian history contending that "myths are alive in traditional societies and continue to determine individual and collective conduct" (36). Surprisingly, Hemingway's free adaptation, Captain Khorshid, also portrays this primordial interplay between light and darkness. Unlike Hemingway's To Have and Have Not in which Harry Morgan, being a commonplace man, who lives a desperate life struggling to feed his household is eventually doomed to failure; the life of Captain Khorshid takes on mythical implications that eternalizes his presence after death. Khorshid in Persian means the Sun. "Hvare-Khashaete" is the ancient term for Khorshid which is a "Zoroastrian divinity of the Radiant Sun" which was later "contracted to Khuwarshēd continuing in New Persian as Khurshēd" (Ranft 89). The Sun in Persian mythology enjoys mythical grandeur unsurpassed by any other entity:

There can be no doubt, from the testimony of all the ancient historians, that the earliest kind of idolatry among the Persians, as among the Chaldeans and other eastern nations, was the worship of the sun, which continued in all after times to be their highest god, and was adored under the name of Mithras (Christmas 135).

As such, Captain Khorshid's conflict with Khajeh Majed, a local affluent man who monopolizes money, power, and illegal activities, takes on a heroic confrontation of good and evil. In the first scene, Captain Khorshid's large piles of smuggled cigarettes are put to a great fire after Khajeh Majed informs the police of Captain Khorshid's illegal activity. Seeing the bonfire, Captain Khorshid asserts: "I will ignite a flame that would set this whole city on fire" (Nakhoda Khorshid. Dir. Naser Taghvaei). Fire in Persian mythology does not allude to evil destructive energy. It is an emblem of the Sun, and thus, is sacred with purging quality:

Next to the sun, fire held a distinguished rank among the Persian gods. It appears very probable that the sun, the sacred fire, and Mithras, were only representations of the same godhead. Isidore indeed asserts, that the Persians worshipped the sun under the form of fire. The fire was therefore in that country, the holiest of all things. (Christmas 136) 
Fire and the Sun in the ending of the movie are once more highlighted. Fire is demonstrated on his ship in Khorshid's shooting the band of killers and criminals in exile who have rubbed and killed Khajeh Majed. The last scene depicts the ship, Bambak [shark in provincial Southern dialect], approaching the shore containing dead bodies at the sunrise. Captain Khorshid, then, turns into a Christ figure whose material body resurrects into the Sun, a Zoroastrian mythical presentation of eternal divinity. In other words, Khorshid cleanses the city of evil and malice with the fire that is emanated from his soul and is reminiscent of Ahuramazda's granting light over darkness.

Philip Young attributes a typical "Hemingway Code," "made of the controls of honor and courage which in a life of tension and pain make a man a man" (qtd. in Tyler 29). Code hero for Young in Tyler's terms is "the mentor," "who has the wisdom to know how to live properly, because of his adherence to an unspoken code of behavior" (Tyler 29). This prudent old man pattern is portrayed in the figure of Santiago or Harry Morgan also reassigned to Captain Khorshid in its fullest sense. Captain Khorshid, out-Hemingways Hemingway's code hero prototype. The stoic perseverance of Hemingway's hero is manifested in the name of Khorshid's ship, Bambak meaning shark. Khorshid is prepared to face all hardship in life with a ferocity and determination of a shark that traps and devours vice and corruption unrelentingly. The same stoic perseverance is traced in Santiago, in The Old Man and the Sea, who contends that "But man is not made for defeat .... A man can be destroyed but not defeated. (Hemingway 103)." It is noteworthy to take into account that Bambak, as the name of the Khorshid's Ship, which is not a familiar term except for the residents of Southern Iran, is a hypertext barrowed from Najaf Daryabandari's translation of The Old Man and The Sea in 1984. This hypertext intensifies the stoic perseverance of Khorshid in purging the land of Iran from the filth against which Iranians have had ancient legendary associations (battles of Jamshid versus Ahriman or Devil and Kaveh, the Smith against Zahhak, the king who fed on the brains of the youth) and historical gory uprisings embodied in defending Iran against any territorial or economical colonization and rebels against despotism. In other words, Captain Khorshid's struggle against Khajeh Majed which is an adaptation of Harry Morgan's fight against capitalist system, also refers to a lasting and collective unconscious desire of Iranians for freedom and egalitarian tendencies mingled with the spirit of revolution.

The frenetic escalation in the number of translations of To Have and Have not in the late decades owes, on the one hand, to the success of film adaptation and more significantly, to the dire economic conditions that had its influence upon the majority of the population at the turn of the millennium. This economical failure was a byproduct of the 1995 and 2006 sanctions against Iran. These sanctions isolated Iran from trading with universal markets, augmented inflation and unemployment with consequent excruciating effects that threatened a large number of middle class families to go on the verge of falling into the lower class. These debilitating conditions resembles the Depression period in which Harry Morgan is entangled within. It is therefore no exaggeration to claim that translation of Hemingway's fiction in post-Revolution period is a part and parcel of Iranian's attempts to go through the excruciating economic conditions with an adaptive procedure.

Another conspicuous contribution to the reception of Hemingway in Iran is latent within the ideology of the translator evident in their reviews or introductions. Daryabandari, as the most famous translator of The Old Man and the Sea, shows interest in translating Hemingway on the basis of ideological grounds, rather than stylistic prowess. Although Daryabandari acknowledges "Hemingway's The Old Man and the Sea as a masterpiece, (Daryabandari, Najaf: Some Works are Untranslatable) he deems Faulkner as a superior writer for his stylistic prowess (Daryabandari, Najaf: Some Works are Untranslatable). If Faulkner excels in style and innovation, it would be the subject matter as the prerogative left for Hemingway, to grant him eligibility for translation. Indeed, Daryabandari's reason for translation of Hemingway after the Revolution is the advocacy of a particular ideology. Daryabandari's main interest in translating Hemingway is fostered by Ebrahim Golestan who later provided him with A Farewell to Arms. Yet, his fame as a translator is attributed to his translation of The Old Man and The Sea. The Old Man and The Sea, rightfully, symbolizes the stoic, and committed man who undergoes torture, pain, and disappointment. This novel exemplifies Daryabandari and all Persian elites who struggle for their ideological and intellectual aspirations. This ideological implication is explicitly pronounced in Daryabandari's collection of prefaces to his various works:

Whatever we perceive as the interpretation [of The Old Man and the Sea] reflects essentially our own perspective. As such Santiago symbolizes Jesus Christ, the proletariat [the working class] or a nation struggling for freedom and losing it. These interpretations are not contradictory in nature. They proceed in the same direction, reaching the same conclusion, suggesting that the existence of a noble and positive entity in the cosmos never advances smoothly, turning, invariably, into the narrative of martyrdom in the end." (Daryabandari 116)

This emphasis on martyrdom is reiterated a few pages later incorporating the fate of all martyrs:

...he [Santiago] is a loser, as a result of which, he turns into a winner as well. He accepts his failure when he, impeccably, wins. This is the fate of martyrs. For a martyr is a person who wins by defeat. In other words, via his own body and soul, the martyr embodies and actualizes the contradictory truth that defeat and victory are identical. (Daryabandari 119)

Daryabandari appreciates Hemingway and interprets his protagonist as an embodiment of an Iranian man under pressure. In other words, Santiago, for Daryabandari exemplifies an Iranian everyman struggling for freedom though arriving at a loss. Categorizing Santiago as a martyr has strong cultural and ideological overtones. It suggests the assimilation of Santiago into the political milieu of Islamic Revolution and culture, reminiscent of the human casualties of Iranians at war. The word martyr is taken from Islamic ideology employed for the human casualties at war. Moreover, this is no accident that Daryabandari uses Iranian Southern words for some of the technical words. He 
deliberately deploys Southern words to turn Santiago to an Iranian Southern fisherman so as to enforce local identification and, in turn, highlight Persian identity and culture in his translated character.

\section{Conclusion}

The translation of Hemingway's novels in post-Revolution period mostly serves as an adaptive measure to go through economic and societal changes. The Hemingway's code hero with a tough but kindhearted man epitomized in the figure of Santiago and to a lesser degree in the character of Harry Morgan is remolded into Captain Khorshid, a devout Muslim, pious, moral, kind, and principled Iranian man whose sacrifice is a necessary step towards Islamic salvation in line with the ideology of the time promoted to bolster a nation crippled at war. Furthermore, Khorshid's very name touches upon the ancient legendary emblem of a purging deity, the Sun, to whom invocations were paid. In Iranian culture, the Hemingway code hero, is thus sublimated to the status of a deity whose mortality guarantees its resurrection and reincarnation in the figure of the Sun. The radiance of the Sun cleanses the land of the Iranians. This outlook also contributes to the hero-worship in Iranian culture. The film adaptation of To Have and Have not and the increase in the number of translations by the turn of the century, is a mark of Iranian's dire need for some adaptive measure to undergo the inflated economy and unemployment which is parallel to the Depression period depicted in To Have and Have Not. This Persianalization of Hemingway is also noted in Najaf Daryabandari's translation of The Old Man and the Sea employing the Southern regional terms to intensify the Persian experience of man under pressure. Iranians make use of Santiago or Harry to live on their collective unconscious desire, embodied in their legendary and historical struggles for freedom and fight against despotism.

\section{References}

Asselineau, R. (1965). "French Reactions to Hemingway's Works Between the Two World Wars." Asselineau, Roger. The Literary Reputation of Hemingway in Europe. Ed. Roger Asselineau. New York: New York University Press: 3972. Print.

Christmas, H. (1838). Universal Mythology; an Account of the Most Important Systems. London: J.W-Parker, 1838. Print.

Daryabandari, N. (2004). Some Works Are Untranslatable. (2004, December 28) Retrieved from. 28 December 2004. Web. 8 December 2016. <http://www.mehrnews.com>.

Daryabandari, N. (2013). In this Respect. Tehran: Karnameh.

Hemingway, E. (1952). The Old Man and the Sea. New York: Scribner's.

Hoveyda, F. (2003). The Shah and the Ayatollah; Iranian Mythology and Islamic Revolution. Westport: Praeger Publishers.

Mazzeno, W. L. (2015). The Critics and Hemingway. New York : Camden House.

Nafisy, H. (2012). Social History of Iranian Cinema: The Globalizing Era, 1984-2010. Vol. 4. Durham: Duke University Press.

Taghvaei, N. Dir. (1987). Nakhoda Khorshid. Prod. Mohammad Ali Soltanzadeh. Film. n.d. Web. 15 october 2016. $<$ http://www.imdb.com/title/tt0122186/awards?ref_=tt_awd $>$.

Prawer, S.S. (1973). Comparative Literary Studies. London: Gerald Duckworth \& Co. Ltd

Ranft, M. (2015). The Esoteric Codex: Zoroastrian Legendary Creatures 2015). Raleigh: Lulu.com

Sadr, H. R. (2006). Iranian Cinema; a Political History. London: I.B. Tauris \& Co. Ltd.

Sanders, J. (2006). Adaptation and Appropriation. Abdington : Routledge.

Tyler, L. (2011). Student Companion to Hemingway. Westport : Greenwood Press. 